Sympozjum

Rok XXIII 2019, nr 2(37), s. 11-45

\author{
ks. Jan Daniel Szczurek \\ Uniwersytet Papieski Jana Pawła II w Krakowie \\ ORCID: 0000-0002-9804-0566; e-mail: jan.szczurek@upjp2.edu.pl \\ https://doi.org/10.4467/25443283SYM.19.021.11423
}

\title{
JEZUS - POSŁANY OD OJCA W DUCHU ŚWIĘTYM - WZÓR MISJONARZA
}

\section{JESUS - SENT FROM THE FATHER IN THE HOLY SPIRIT - A MODEL OF A MISSIONARY}

\begin{abstract}
Abstrakt
Artykuł jest próbą określenia trynitarnych podstaw misji i wskazania wniosków praktycznych. Składa się z trzech części poświęconych kolejno tożsamości Posłanego, celowości Jego posłania i uczestnictwie misjonarzy w posłannictwie Chrystusa i Ducha Świętego.

Tożsamość Posłanego (jednorodzonego Syna i Ducha Świętego) jest ukazana z perspektywy wewnątrztrynitarnych relacji. Syn został posłany przez Ojca, aby był „Nauczycielem, Królem i Kapłanem wszystkich” (LG, 13a). Duch Święty zaś „niesie” światu zmartwychwstałego Chrystusa i gromadzi Jego uczniów „w jednym Kościele Chrystusa” (KKK 1097). W ten sposób dokonuje się zbawianie świata, które jest głównym celem posłania Syna (por. J 3,17). Uczestnictwo misjonarza w posłaniu wcielonego Syna polega na realizacji Jego kapłaństwa wyrażającego się w mesjańskim triplex munus (nauczanie, uświęcanie, kierowanie albo w funkcji: prorockiej, ofiarniczej i pasterskiej). Jezus z Nazaretu jest wzorem dla misjonarza jako najwyższy i wieczny Kapłan, który „przez Ducha wiecznego złożył Bogu samego siebie jako nieskalaną ofiarę” (Hbr 9,14).
\end{abstract}


Główny wniosek wyraża się w stwierdzeniu, że budowanie wspólnoty zbawionych musi być przede wszystkim patrocentryczne i dziejozbawczo komplementarne, czyli chrystologicznie i równocześnie pneumatologicznie ugruntowane.

Słowa kluczowe: Trójca Święta, Duch Święty, misyjny wymiar Kościoła, misje, misjonarz, objawienie, zbawienie, kapłaństwo

\section{Abstract}

The article is an attempt to determine the Trinitarian foundations of the mission and to indicate its practical conclusions. It consists of three parts dedicated in turn to the identity of the Messenger, the purposefulness of his mission and the participation of missionaries in the mission of Christ and of the Holy Spirit.

The identity of the messenger (the only-begotten Son and the Holy Spirit) is shown from the perspective of intra-trinitarian relations. The Son was sent by the Father to be "teacher, king and priest of all” (Lumen gentium, 13a). The Holy Spirit, in turn, „brings” the risen Christ to the world and gathers his disciples ,in one Church of Christ" (Catechism of The Catholic Church, 1097). In this way the world is going to be saved, which is the main goal of the sending of the Son (cf. Jn 3:17). The missionary's participation in the mission of the incarnated Son consists in the realization of his priesthood expressed in the messianic triplex munus (teaching, sanctifying, directing, or: in the prophetic, sacrificial and pastoral function). Jesus of Nazareth is a model for the missionary as the high and ternal Priest who "offered himself, blameless as he was, to God through the eternal Spirit" (Heb 9:14).

The main conclusion is expressed in the statement that the redeemed community building must be primarily patricentric and salvifically complementary: Christologically and pneumatologically grounded on the same time.

Keywords: Trinity, Holy Spirit, missionary dimension of the Church, missions, missionary, revelation, salvation, priesthood, triplex munus 
Temat sugeruje, że Jezus z Nazaretu był misjonarzem. Nie nazywamy Go w ten sposób, więc nasuwa się odpowiedź negatywna: nie był misjonarzem, przecież był Mesjaszem. Skoro tak, to czy może być wzorem misjonarza? Poszukujemy więc odpowiedzi na pytanie, na jakiej podstawie może On być wzorem misjonarza, pomimo tego, że nie był misjonarzem w naszym rozumieniu, a jeśli jednak może być wzorem, to w jaki sposób zrealizował On swe posłannictwo.

O misyjności Jego Kościoła przypomniał nam II Sobór Watykański, gdy nawiązując do Konstytucji dogmatycznej o Kościele Lumen gentium ${ }^{1}$, w Dekrecie o działalności misyjnej Kościoła Ad gentes divinitus stwierdza wprost, że „Kościół pielgrzymujący jest misyjny ze swej natury (natura sua missionaria est), ponieważ swój początek bierze wedle planu Ojca z posłania (ex missione) Syna i z posłania Ducha Świętego"2. Każdy zatem, kto poczuwa się do jedności z Kościołem, nie może się wyrzec swej misyjności. Ten właśnie Duch Święty „wzbudza w sercach jednostek powołanie misyjne"3. W tym kontekście pojawia się jeszcze inne pytanie: w czym ktoś mający powołanie misyjne może i powinien naśladować Jezusa, wcielonego Syna Ojca?

\section{Tożsamość Posłanego}

Przychodząc do swoich, którzy Go jednak nie przyjęli (por. J 1,11), Jezus z Nazaretu objawia swą tożsamość, którą uwierzytelnia sam Ojciec (por. J 5,37; 8,18) i potwierdza Jego Duch (J 15,26). Jako jednorodzony Syn Ojca objawia przede wszystkim Jego i jest Jego „egzegetą":

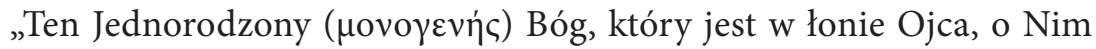

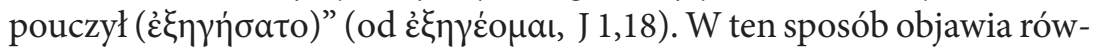
nocześnie swoje naturalne synostwo, a w konsekwencji swoje bycie zrodzonym odwiecznie przez Ojca. Takie bycie jest niezwykle ważne dla

1 II Sobór WATYKAŃski, Konstytucja dogmatyczna o Kościele Lumen gentium, Rzym 1964 (dalej: LG), 2.

2 Tenże, Dekret o misyjnej działalności Kościoła Ad gentes divinitus, Rzym 1965 (dalej: DM), 2a.

3 DM, 23a. 
całego procesu objawienia, ponieważ leży u podstaw jego wiarygodności: „Boga nikt nigdy nie widział” (J 1,18; por. $1 \mathrm{Tm} 6,16$ ), a ,jedynie Ten, który jest od Boga, widział Ojca" ( 6,46$)$, dlatego objawia nam to, co Mu Ojciec nakazał (J 12,48). U podstaw wiarygodności Syna leży nie tylko wypełnianie woli Ojca, ale przede wszystkim Jego podobieństwo do Ojca, dzięki czemu ten, kto widzi Syna, widzi i Ojca (por. J 12,45). Nie jest to podobieństwo formy, zewnętrzne, ale istotowe, co do natury, polegające na tym, że Ojciec jest „w” Synu (J 10,38; 14,10).

Nie tylko Ojciec daje świadectwo o jednorodzonym Synu. Daje je również Duch Święty, który przychodzi przez Syna i daje świadectwo o Synu - przychodzi przez Syna, który Go tchnie po swoim zmartwychwstaniu (J 20,22), a potem daje o Nim świadectwo i przypomina objawioną przez Niego prawdę (J 14,26; 15,26). Nie tylko daje świadectwo, ale wprost uzdalnia chrześcijanina do wyznania wiary, co św. Paweł wyraża w stwierdzeniu, że bez pomocy Ducha Świętego nikt nie może nawet powiedzieć „Panem jest Jezus” (1 Kor 12,3). Ten fakt nierozłączności Syna i Ducha Świętego bardzo mocno podkreśla H. U. von Balthasar.

Wspomniana wyżej nierozłączność Syna i Ducha Świętego w zbawczym działaniu rodzi pytanie o rolę Ducha Świętego w odwiecznym rodzeniu Syna przez Ojca 5 . Takie pytanie wynika stąd, że Duch Święty współdziała przy cielesnym (drugim) narodzeniu, a wiedzę naszą o relacjach wewnątrztrynitarnych możemy czerpać jedynie ze zbawczego zaangażowania osób Bożych na podstawie zasady (Grundaxiom) sformułowanej przez K. Rahnera, która mówi, że Trójca zbawcza jest Trójcą wewnętrzną i na odwrót: „W Trójcy Świętej działającej w ekonomii historii zbawienia i w ekonomii historii objawienia doświadczyliśmy już Trójcy immanentnej samej w sobie"'. Skoro Duch Święty jest tak ściśle związany z całym posłannictwem wcielonego Syna, co widać już na

${ }^{4}$ Por. H. U. von Balthasar, Teologika. Duch Prawdy, t. 3, Kraków 2005, s. 154.

5 Por. M. Serretti, Il mistero della eterna generazione del Figlio. Attraverso l'opera di Hans Urs von Balthasar, Roma 1998, s. 97-99.

${ }^{6}$ K. Rahner, Podstawowy wykład wiary. Wprowadzenie do pojęcia chrześcijaństwa, Warszawa 1987, s. 118. Krytyka sformułowania „i na odwrót” w przytoczonej zasadzie, zob.: B. J. Hilberath, Der Personbegriff der Trinitätstheologie in Rückfrage von Karl Rahner zu Tertullians „Adversus Praxean”, Innsbruck-Wien 1986, s. 50-53. 
samym początku Jego publicznej działalności (por. Łk 4,16-21), to w takim razie należy domniemywać, że również w relacjach wewnątrztrynitarnych zachodzi analogiczny związek.

Poszukując potwierdzenia jego istnienia, trzeba pamiętać, że choć we Wcieleniu współdziałają wszystkie trzy osoby Boże, to w odwiecznym akcie rodzenia Ojciec działa (rodzi) sam. Sobór Florencki w Dekrecie dla Jakobitów wyjaśnia, że „Tylko Ojciec zrodził Syna ze swej substancji. Jedynie Syn jest zrodzony tylko z Ojca”. Jest to nawiązanie do nauki IV Soboru Laterańskiego: „Ojciec nie pochodzi od nikogo, Syn od samego tylko Ojca"”. Pomimo tego H. U. von Balthasar uważa, że chociaż Ojciec pozostaje w swej bezprzyczynowości, to jednak w Duchu Świętym ma ciągle nowy bodziec (Ansporn) dla swej miłości, przez co Duch Święty należy do sfery wynikowości i równocześnie jest współpotwierdzeniem ojcowskiej źródłowości ${ }^{8}$. Te określenia tak charakterystyczne dla von Balthasara wskazują na niewyrażalność ludzkim językiem głębi tajemnicy Trójcy wewnętrznej i podkreślają jej apofatyczny charakter.

Wspomniana „sfera wynikowości” stanowi „zabezpieczenie” przed pokusą naruszenia starożytnej zasady đákıৎ, czyli „porządku” osób Bożych, według której Ojciec jest absolutnym początkiem wszystkiego, również w „łonie” samej Trójcy Świętej, jest „przed” Synem i „przed” Duchem Świętym, Syn „przed” Duchem Świętym, przy czym owo „przed” nie może być pojmowane w kategoriach czasu (stworzonego). Gdyby bo-

7 A. Baron, H. Pietras (red.), Dokumenty Soborów Powszechnych, tekst grecki, łaciński, polski, t. 2, 869-1312, Kraków 2002, „Źródła Myśli Teologicznej” 26 (dalej: DSP II), s. 220-221: Pater a nullo, Filius autem a solo Patre (DS, 800); TENŻE, Dokumenty Soborów Powszechnych, tekst grecki, łaciński, polski, t. 3, 1414-1445, Kraków 2007, „Źródła Myśli Teologicznej” 30 (dalej: DSP III), s. 580-581: Solus Pater de substantia sua genuit Filium. Solus Filius de solo Patre est genitus (DS, 1330). Por.: a solo Patre (DS, 75). Tomasz z Akwinu uważa, że nie jest możliwe, aby Duch Święty był zasadą miłości (principium diligendi) Ojca i Syna, S. th. I q. 37, a. 2. Natomiast Durrwell mówi wprost: „Rodzenie Syna jest nie do pomyślenia bez Ducha Świętego” („La génération du Fils est impensable sans l'esprit Saint"). F.-X. Durrwell, Le Père. Dieu en son mystère, Paris 1987, s. 140. Oprócz tego na temat taxis zbawczej i wewnątrztrynitarnej u H. U. von Balthasara, Teologika. Duch..., dz. cyt., s. 160-161; zob. M. Serretti, Il mistero..., dz. cyt., s. 100.

${ }^{8}$ K. J. WALLner, Gott als Eschaton. Trinitarische Dramatik als Voraussetzung göttlicher Universalität bei Hans Urs von Balthasar, Wien 1992, s. 220. 
wiem przyjąć na przykład, że Ojciec rodzi Syna w Duchu Świętym9 to mogłoby to oznaczać najpierw wykluczenie Syna z udziału w tchnieniu Ducha Świętego, a następnie utożsamienie Ducha Świętego z substancją Ojca. Tymczasem Duch Święty pochodzi od Ojca i od Syna (albo od Ojca przez Syna, w ujęciu greckim) na mocy jednego tchnienia, a Syn jest zrodzony z substancji Ojca jak światłość ze światłości ${ }^{10}$. Ponadto, Katechizm Kościoła katolickiego stwierdza wprost: „Wieczny początek Ducha Świętego nie jest jednak bez związku z początkiem Syna" ${ }^{11} \mathrm{i}$ uzasadnia to odwołaniem się do „Wyznania wiary” XI Synodu w Toledo (Symbolum Toletanum XI, 675 r.): „Nie mówi się, że jest tylko Duchem Ojca [albo tylko Syna], ale Duchem Ojca i Syna"'12.

Zatem nie należy stawiać Ducha Świętego „przed” Synem, a tym bardziej „przed” Ojcem. Tymczasem, w opinii J. Galot, F.-X. Durrwell tak właśnie czyni, gdy przypisuje Duchowi Świętemu bycie zasadą wszelkiego uosabiania (principe de toute personalisation) ${ }^{13}$. Jest to konsekwencja zbyt radykalnego utożsamienia Ducha Świętego z miłością Bożą. Tak określone „miejsce” Ducha Świętego w Trójcy Świętej, jak słusznie zauważa Galot, prowadzi do zredukowania różnicy między odwiecznym

9 Takiej formuły używa Durrwell w tytule podrozdziału: Dieu engendre dans l'Esprit Saint. F.X. Durrwell, Le Père..., dz. cyt., s. 140-142.

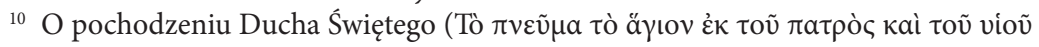

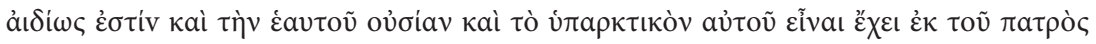

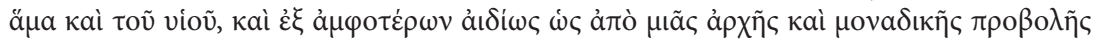

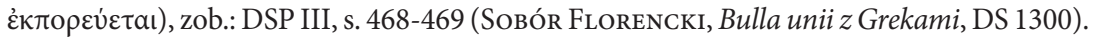

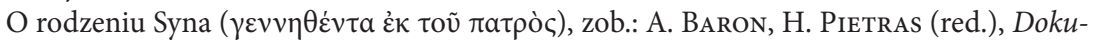
menty Soborów Powszechnych, tekst grecki, łaciński, polski, t. 1, 325-787, Kraków 2002, „Źródła Myśli Teologicznej” 24 (dalej: DSP I), s. 24-25 (Sobór Nicejski, Wyznanie wiary 318 Ojców, DS 125).

${ }^{11}$ Katechizm Kościoła katolickiego, Poznań 1994 (dalej: KKK), 245. W wersji łacińskiej: „Aeterna tamen Spiritus Sancti origo sine nexu cum illa Filii non est”. Catechismus Catholicae Ecclesiae, Citta del Vaticano 1997 (dalej: CCE), 245.

${ }^{12}$ KKK, 245. W wersji polskiej Katechizmu brak słów w nawiasie kwadratowym "[]": "qui tamen nec Patris tantum nec Filii tantum, sed simul Patris et Filii Spiritus dicitur". CCE 245.

13 J. Galot, L'Esprit Saint et la spiration, „Gregorianum” 74 (1993), s. 241-256, F.X. Durrwell, L’Esprit Saint de Dieu, Paris 1983, s. 160. 
rodzeniem i odwiecznym tchnieniem. Nie można zaakceptować takiej redukcji przede wszystkim dlatego, że rodzenie jest źródłem podobieństwa Syna do Ojca, natomiast tchnienie (czynne) - podobieństwa do Ojca i Syna równocześnie ${ }^{14}$.

Jak widać, z powodu skromności danych objawienia, niewiele jesteśmy w stanie powiedzieć o roli Ducha Świętego w odwiecznym rodzeniu Syna. Dlatego tym bardziej nie można zapominać o tym, że „Duch przenika (...) głębokości Boga samego” (1 Kor 2,10). Wprawdzie „przenikanie" (od غ̇pavváw, badać przeszukiwać cośs ${ }^{15}$ ) nie wskazuje na jakieś współdziałanie Ducha Bożego (por. 1 Kor 2,11b) w akcie rodzenia Syna, ale wskazuje na Jego tajemniczą aktywność wewnątrz nieogarnionej „przestrzeni” trynitarnego życia. Ze względu na analogię do aktywności ludzkiego ducha (1 Kor 2,11a), która ma charakter poznawczy („tego,

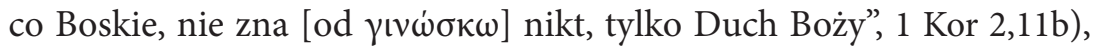
można domniemywać Jego aktywną obecność przy rodzeniu Syna, przynajmniej na poziomie świadomości, przy założeniu, że akt rodzenia jest aktem intelektualnym (per modum intellectus) ${ }^{16}$.

O wewnątrztrynitarnym rodzeniu Syna mówi także wyznanie wiary Soboru Nicejskiego. Sobór w swoim wyznaniu wiary użył imiesłowu aorystu biernego $(\gamma \varepsilon v \nu \eta \theta \varepsilon ́ v \tau \alpha \text {, DS } 120)^{17}$ do wyrażenia odwiecznego aktu zrodzenia/rodzenia ${ }^{18}$. Zasygnalizowana wyżej a-czasowość tego aktu w sposób szczególnie wyraźny została wprowadzona do wspomnianego „Wyznania wiary” XI Synodu w Toledo. Przede wszystkim należy zwrócić uwagę na sposób wyrażania się o tej czynności Ojca (aspekt grama-

14 „L'Esprit Saint ressemble au Père et au Fils, de la même manière que le Fils ressemble au Père, et la spiration, comme la generation, tend à produire cette ressemblance". J. GALOT, L'Esprit..., dz. cyt., s. 257.

15 R. Popowski, Wielki słownik grecko-polski Nowego Testamentu, Warszawa 1995, n. 2037.

16 S. th. I, q. 37, a. 1 corp.; por. S. th. I q 27, a. 1. 3. 5.

${ }_{17}$ H. Denzinger, Enchiridion symbolorum definitionum et declarationum de rebus fidei et morum. Kompendium der Glaubensbekenntnisse und kirchlichen Lehrentscheidungen. Lateinisch-Deutsch, Freiburg im Br.-Basel-Rom-Wien 1999 (dalej: DS).

18 Por. J. D. Szczurek, Bóg Ojciec w tajemnicy Trójcy Świętej. Elementy patrologii, Kraków 2003, s. 188-190. 
tyczny): orzeczenie „zrodził” (genuit) ma formę czasu przeszłego dokonanego, zarówno w języku polskim, jak i łacińskim (perfectum). Jednak tej formie gramatycznej towarzyszą dwa sformułowania, które nadają jej specyficzny sens: „bez początku” (sine initio), „nie zaprzestał” (nec desiit). Wskazują one na inną rzeczywistość, w której nie funkcjonuje rozróżnienie na aspekt niedokonany i dokonany. Innymi słowy odwieczne rodzenie jest czynnością nieustannie się dokonującą, bez początku i bez końca. Taki stan rzeczy wyraża imiesłów czasu teraźniejszego użyty w wyrażeniu: „rodzący Ojciec” (generans Pater, DS 531). Choć to stwierdzenie brzmi paradoksalnie (czynności nie mogą być równocześnie dokonane i niedokonane), to jednak jest spójne z innym stwierdzeniem: Ojciec zawsze ma Syna, dla którego jest Ojcem ${ }^{19}$ albo: „I nigdy nie był Ojciec bez Syna ani Syn bez Ojca"20. Jest to konsekwencja relacyjności, wskazująca równocześnie na nieustanny dynamizm życia, co w objawieniu jest wyrażone w imieniu Boga „Jestem, który jestem” (Wj 3,14; por. J 8,28). Oznacza to zatem, że Syn nieustannie jest rodzony przez Ojca, również w stanie wcielenia, w czasie całego Jego ludzkiego życia. W objawieniu rąbek tej tajemnicy został uchylony w słowach Jezusa: „Ojciec bowiem miłuje Syna i ukazuje Mu to wszystko, co On sam czyni" (J 5,20) oraz "Ja sam z siebie nic czynić nie mogę" (J 5,30). Słusznie więc von Balthasar zastanawia się, „czy boska istota nie staje się (...) czymś tak samo «ruchomym» jak samo wydarzenie pochodzeń?". Jego odpowiedź jest twierdząca: „A jeśli ofiarowanie się Ojca Synowi oraz ich Obu Duchowi nie jest dowolne ani wymuszone, lecz odpowiada najgłębszej istocie Boga, to tą najgłębszą istotą (...) może przecież ostatecznie być tylko miłość"21. Obrazem doczesnym tak pojętego nieustannego rodzenia może być brzmienie utworu muzycznego - jego dźwięki dopóty się rozlegają, dopóki jest on wykonywany.

${ }^{19}$ Jest to nauka Soboru Nicejskiego (325 r.) skierowana przeciw arianom, czyli tym, „którzy mówią: «był kiedyś czas, kiedy Go nie było»”. DSP I, s. 24-25 (DS 126).

20 I. Bokwa (red.), Breviarium fidei. Wybór doktrynalnych wypowiedzi Kościoła, Poznań 2007 (dalej: BF) 211 (DS 617).

${ }^{21}$ H. U. von Balthasar, Teologika. Prawda Boga, t. 2, Kraków 2004, s. 126. Autor nawiązuje tu do sformułowania użytego w „Wyznaniu Damazego” (Fides Damasi): „Pater Filium genuit, non voluntate, nec necessitate, sed natura” (DS 71; por. DS 526). 
W analogiczny sposób możemy mówić także o pochodzeniu Ducha Świętego, czyli o tchnieniu czynnym. Ono również jest a-czasowe (bezczasowe), co wyraźnie stwierdza wyznanie wiary Synodu we Friuli (796 r. lub 797 r.): Duch Święty ,jest prawdziwym Bogiem (...): nie zrodzony ani nie stworzony, lecz pochodzący bezczasowo (intemporaliter) i nierozdzielnie od Ojca i Syna. Zawsze jest, był i będzie wspólistotny, współwieczny i równy Ojcu i Synowi. I nigdy nie był Ojciec albo Syn bez Ducha Świętego ani Duch Święty bez Ojca i Syna"22. Wyznanie stanowi rozwinięcie wyznania konstantynopolitańskiego: opisuje oba pochodzenia wewnątrztrynitarne w analogiczny sposób. Stwierdzenie, że „nigdy nie był Ojciec albo Syn bez Ducha Świętego" wyklucza przypuszczenie, że Duch Święty w jakikolwiek sposób jest „przed” Ojcem. $\mathrm{Z}$ drugiej strony mocno podkreśla odwieczne współistnienie (współzachodzenie) rodzenia i tchnienia czynnego albo ich „równoczesność”, chociaż równoczesność jest kategorią czasową. Jako taka nie jest więc w tym kontekście określeniem adekwatnym. Wspomniane wyżej wyznanie toledańskie (675 r.) stwierdza to bardzo wyraźnie: „między rodzącym Ojcem i zrodzonym Synem albo pochodzącym Duchem Świętym nie było, jak wierzymy, żadnego odstępu czasu, w którym albo Rodziciel poprzedzałby kiedyś Zrodzonego, albo Rodziciel nie miałby Zrodzonego, albo pochodzący Duch ukazałby się później od Ojca lub Syna"23. Oznacza to, że także pochodzenie Ducha Świętego przez tchnienie czynne jest bez początku i bez końca oraz że nieustannie trwa w odwiecznym boskim „teraz". Nieprzemijająca teraźniejszość tego aktu tchnienia jest znacznie wyraźniej ukazana niż rodzenia Syna, ponieważ wyznanie toledańskie używa form czasu teraźniejszego: „pochodzi”, „pochodzący” (procedit,

22 I. Bokwa (red.), Breviarium fidei. Wybór doktrynalnych wypowiedzi Kościoła, Poznań 2007, s. 122 (n. 211). „Spiritus namque Sanctus verus Deus (...) est: non genitus nec creatus, sed ex Patre Filioque intemporaliter et inseparabiliter procedens. Consubstiantialis, coaeternus et aequalis Patri Filioque semper est, erat et erit. Et numquam fuit Pater aut filius sine Spiritu Santo, nec Spiritus Sanctus sine Patre et Filio" (DS 617).

${ }_{23}$ BF 184; „inter generantem Patrem et generatum Filium vel procedentem Spiritum Sanctum nullum fuisse credimus temporis intervallum, quo aut genitor genitum aliquando praecederet, aut genitus genitori deesset, aut procedens Spiritus Patre vel Filio posterior appareret" (DS 531, twierdzenie 29). 
procedens, DS 527. 531), zgodnie zresztą z formą użytą w tekście Janowym $(J 15,26)^{24}$. O takim trwaniu tchnienia, przynajmniej z perspektywy doczesnej - mówi, jak się wydaje, fakt zstępowania Ducha Świętego na Jezusa podczas chrztu w Jordanie poświadczony przez Ewangeli-

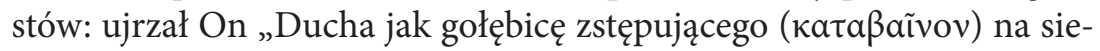
bie” (Mk 1,10); „ujrzał Ducha Bożego zstępującego jak gołębicę i przychodzącego na Niego" (Mt 3,16; por. Łk 3,22) oraz poświadczony także przez Jana Chrzciciela, który ujrzał „Ducha zstępującego i spoczywa-

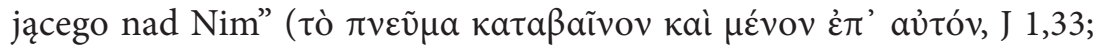
por. J 1,32; Mt 3,16; Łk 3,22). Użyte tu imiesłowy czasu teraźniejszego strony czynnej wskazują na czasową rozciągłość czynności i równocześnie na jej trwałość poprzez nawiązanie do spoczywania. W wyznaniu wiary Soboru Konstantynopolskiego akt odwiecznego tchnienia czynnego jest wyrażony przy pomocy imiesłowu czasu teraźniejszego „po-

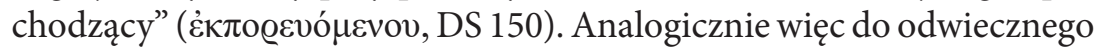
rodzenia możemy o tchnieniu czynnym powiedzieć, że jest bez początku i bez końca, czyli że dokonuje się nieustannie w odwiecznym boskim „teraz". Jest równocześnie dokonany i niedokonany oraz że nie jest aktem dokonującym się z konieczności albo dobrowolnie $e^{25}$.

Odwieczne rodzenie jest fundamentem innej cechy Jezusa bardzo ważnej z punktu widzenia misyjnego posłannictwa. Rodzenie jest źródłem podobieństwa: „[Adamowi urodził się] syn, podobny do niego jako jego obraz" (Rdz 5,3). W wyniku tak wyjątkowego zrodzenia, jakim jest odwieczne rodzenie przez Ojca, powstaje tak wielkie podobieństwo, że przyjmuje ono postać „odblasku Jego chwały” i „odbicia Jego istoty” (Hbr 1,3). Dzięki temu ten, kto zobaczył Jezusa, „zobaczył także i Ojca" (J 14,9). Odwieczne rodzenie jako nieustanny proces sprawia nie tylko podobieństwo co do natury, a dokładniej współistotnośćc ${ }^{26}$, ale także relację niepowtarzalnej bliskości, co wyrażamy w pojęciu perychorezy trynitarnej: „Ja jestem w Ojcu, a Ojciec we Mnie” (J 14,10; por. J 10,38). Dlatego właśnie „Ojca nikt nie zna, tylko Syn, i ten, komu

\footnotetext{
24 J. D. Szczurek, Bóg Ojciec..., dz. cyt., s. 193-194.

25 Por. tamże, s. 193. 3-4.

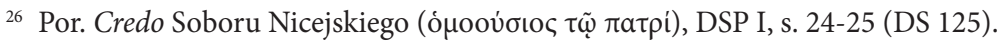


Syn zechce objawić” (Mt 11,27). Będąc jednorodzonym Synem, mógł nam więc objawić Ojca i dokonał tego zgodnie z Jego wolą, stając się Jego „egzegetą" (o czym była mowa wyżej). Dlatego też Jezus wyjaśniał swoim uczniom: „Nauka, którą słyszycie, nie jest moja, ale Tego, który Mnie posłał, Ojca" (J 14,24).

Innym ważnym elementem tożsamości Jezusa, obok bycia odwiecznie zrodzonym, jest Jego człowieczeństwo. On bowiem „istniejąc w postaci Bożej, nie skorzystał ze sposobności, aby na równi być z Bogiem, lecz ogołocił samego siebie, przyjąwszy postać sługi, stawszy się podobnym do ludzi" (Flp 2,6-7). Ten jednorodzony Syn Ojca jako Jego odwieczne Słowo stał się ciałem i zamieszkał wśród nas (por. J 1,14), bo Ojciec tak „,umiłował świat, że Syna swego jednorodzonego dał, aby każdy, kto w Niego wierzy, nie zginął” (J 3,16). Jan Chrzciciel, gdy tylko Go zobaczył, rozpoznał w Nim Syna Bożego: „Ujrzałem Ducha, który jak gołębica zstępował z nieba i spoczął na Nim” (J 1,32) i oświadczył: On „jest Tym, który chrzci Duchem Świętym" (J 1,33). Janowe świadectwo doskonale współbrzmi ze świadectwem samego Jezusa po odczytaniu w synagodze nazaretańskiej proroctwa Izajasza (Iz 61,1-2): „Dziś spełniły się te słowa Pisma, któreście słyszeli” (Łk 4,21). Jan Paweł II tak komentuje to wydarzenie, podkreślając rolę Ducha Świętego: „W ten sposób wyznał i zarazem obwieścił, że On jest tym «Namaszczonym» przez Ojca, że jest Mesjaszem, czyli Chrystusem, w którym mieszka Duch Święty jako dar Boga samego, i który posiada pełnię tego Ducha; który naznacza «nowy początek» udzielania się Boga ludzkości w Duchu Świętym"27.

Istnieje ścisły związek między wcieleniem Syna Bożego, Jego publiczną działalnością i aktywnością Ducha Świętego. W samym wydarzeniu Wcielenia zaangażowanie Ducha Świętego jest bardzo wyraźnie objawione. To, co zapowiedział anioł Gabriel w słowach: „Duch Święty zstąpi na Ciebie i moc Najwyższego osłoni Cię" (Łk 1,35), spełniło się, gdy po zaślubinach z Józefem, zanim zamieszkali razem, Maryja „znalazła się brzemienną za sprawą Ducha Świętego" (Mt 1,18). Fakt ten Kościół wyraził lapidarnie w swoim wyznaniu wiary na Soborze Konstantynopolitańskim (Wyznanie wiary 150 Ojców, 381 r.): „Wierzymy (...)

${ }^{27}$ Jan Pawe€ II, Encyklika Dominum et Vivificantem, Rzym 1986 (dalej: DeV), 18. 
w jednego Pana Jezusa Chrystusa (...), który (...) przyjął ciało za sprawą (દ̉k) Ducha Świętego"28.

Chociaż Wcielenie jest dziełem wszystkich osób Bożych, o czym zapewnia nas IV Sobór Laterański (1215 r.), stwierdzając, że "Jednorodzony Syn Boży - Jezus Chrystus, wcielony poprzez wspólne [działanie] całej Trójcy"29, to jednak współdziałanie Ducha Świętego ma tu szczególne znaczenie, ponieważ objawia nam „absolutną inicjatywę Boga we Wcieleniu” ${ }^{30}$ i stanowi zapoczątkowanie nowego stworzenia poprzez „nowe narodziny dzieci Bożych w Duchu Świętym przez wiarę" ${ }^{\prime \prime}$, co jest podkreślone w nauczaniu Synodu we Friuli (796 r. ${ }^{32}$.

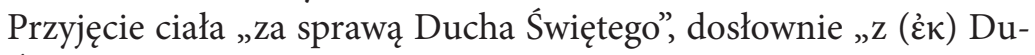
cha Świętego", oznacza cud dziewiczego poczęcia Jezusa. Fakt ten objawia nam fundamentalną prawdę o Nim, a mianowicie że jest źródłem życia człowieka, w tym wypadku jego życia biologicznego ${ }^{33}$. Jednak to nie wyczerpuje Jego zbawczego zaangażowania. Von Balthasar przypomina, że Duch Święty jest nie tylko Duchem Ojca, ale i Duchem Syna. Jako Duch Ojca przybywa do Maryi, ale jako Duch Syna skłania Go do posłuszeństwa i przyjęcia człowieczeństwa. Dzięki temu, zauważa von Balthasar, „wcielenie $i$ «namaszczenie» po prostu się pokrywają, a podobnie też pokrywa się «namaszczenie» człowieczeństwa Chrystusa z boską naturą i z Duchem Świętym" ${ }^{34}$.

Dziewicze poczęcie Jezusa zapoczątkowało nowy sposób obecności i działania Boga w świecie. Jan Paweł II zauważa, że Mesjasz Chrystus jest nie tylko Tym, który „„przychodzi» w Duchu Świętym”, ale zarazem Tym, który „ «przynosi» Ducha Świętego”, co widać szczególnie wyraźnie

28 DSP I, s. 68-69 (DS 150).

29 „Unigenitus Dei Filius, Iesus Christus, a tota Trinitate communiter incarnatus...”. DSP I, s. 222-223 (DS 801).

30 KKK 503.

31 KKK 505.

32 Por. T. D. Łukaszuk, Ty jesteś Chrystus, Syn Boga żywego. Dogmat chrystologiczny w ujęciu integralnym, Kraków 2000, s. 351. 367.

33 Por. J. D. Szczurek, Trójjedyny. Traktat o Bogu w Trójcy Świętej jedynym, Kraków 2003, s. 148.

${ }^{34}$ H. U. von Balthasar, Teologika. Duch..., dz. cyt., s. 161. 
w Wieczerniku w dzień zmartwychwstania (DeV 19b; por. J 20,22-23). Ten nierozerwalny związek Jezusa z Duchem Świętym sprawia, że za von Balthasarem można przypomnieć Ireneuszową analogię o dwóch rękach Ojca: „poprzez oba aspekty Ducha ostatecznym sprawcą okazuje się (działający przez swoje «obie ręce») Ojciec”35. „Oba aspekty” oznaczają tu bycie Duchem Ojca (przekazywanie życia) i równocześnie bycie Duchem Syna (posłuszeństwo Ojcu).

„Przyniesiony” przez Chrystusa Duch Święty sprawia także dziewicze poczęcie Kościoła, dzięki któremu On „pozostaje” w Kościele, a Pięćdziesiątnica jest tego pierwszym wyraźnym znakiem. Istnieje daleko idąca analogia między działaniem w świecie Syna Bożego wcielonego i działaniem zesłanego Ducha Świętego: jest nim gromadzenie ludzi sprawiedliwych „w Kościele powszechnym u Ojca”36.

W czasie swej publicznej działalności bowiem Jezus jako Dobry Pasterz gromadził swoje owce w jednej owczarni $(\mathrm{J} 10,16)$ i oddał swoje życie, aby „rozproszone dzieci Boże zgromadzić w jedno” (J 11,51-52). Gdy zaś został „nad ziemię wywyższony, [przyciągnął] wszystkich do siebie” (J 12,32). Dlatego właśnie Ojciec umiłował Go i pozwolił Mu odzyskać swoje życie (por. J 10,17). Dokonał tego mocą Ducha Świętego, co podkreśla św. Piotr, mówiąc, że Jezus został „powołany do życia Duchem” (1 P 3,18), ponieważ, jak zauważa św. Paweł, Ojciec wskrzesza z martwych mocą Ducha Świętego, który mieszka w Jego synach (por. Rz 8,11). Pragnąc podkreślić rolę Ducha Świętego w wywyższeniu Jezusa Chrystusa, Jan Paweł II zauważa, że „mesjańskie «wyniesienie» Chrystusa w Duchu Świętym osiąga w zmartwychwstaniu swój zenit. Równocześnie też (...) Chrystus zmartwychwstały spełnia z jednej strony obietnicę Bożą, już wyrażoną przez usta Proroka: «I dam wam serce nowe i ducha nowego tchnę do waszego wnętrza (...) Ducha mojego» (Ez 36,26-27; por. J 7,37-39; 19,34), z drugiej strony spełnia własną obietnicę daną Apostołom w słowach: «jeżeli odejdę, poślę Go do was» (J 16,7). Jest to On: Duch

35 Tamże, s. 162.

${ }^{36}$ LG 2. Na temat misyjnego wymiaru tajemnicy Trójcy Świętej, zob.: K. DAUGHERTY, "Missio Dei”. The Trinity and Christian Missions, „Evangelical Review of Theology” 2(31) (2007), s. 152-154. 
Prawdy, Paraklet, zesłany przez Chrystusa zmartwychwstałego, aby przemieniał nas na Jego podobieństwo ${ }^{37 n 38}$.

$\mathrm{Na}$ samym początku istnienia Kościoła posłany od Ojca przez Zmartwychwstałego Duch Święty (por. Dz 2,33) sprawił, że „jeden duch i jedno serce ożywiały wszystkich wierzących" (Dz 4,32). Jednoczące działanie Ducha Świętego podkreśla św. Paweł, gdy stwierdza: „Wszyscyśmy bowiem w jednym Duchu zostali ochrzczeni, aby stanowić jedno Ciało" (1 Kor 12,13) oraz gdy życzy Koryntianom, aby „dar jedności w Duchu Świętym” był udziałem ich wszystkich (2 Kor 13,13). Jeszcze mocniej jednoczące działanie Ducha Świętego św. Paweł uświadamia Efezjanom: obrzezani i nieobrzezani „w jednym Duchu [mają] przystęp do Ojca” przez Chrystusa (Ef 2,18). Dzięki temu my wszyscy „sprawujemy kult w Duchu Bożym" (Flp 3,3; por. J 4,23-24, Jud 20). W wymiarze indywidualnym zaś przez chrzest Duch Święty jednoczy nas z Bogiem (Ojcem i Chrystusem), który „z miłosierdzia swego zbawił nas przez obmycie odradzające i odnawiające w Duchu Świętym" (Tt 3,5). Dlatego też aktualna więź z Nim jest rozpoznawalna „po Duchu, którego nam dał" (1 J 3,24).

Duch Święty jest nie tylko Duchem uświęcenia i jedności, ale także prawdy (J 14,17; 15,26; 16,13; por. $1 \mathrm{~J} 5,6)$. Obietnica Jezusa dana w słowach: „Gdy zaś przyjdzie On, Duch Prawdy, doprowadzi was do całej prawdy” (J 16,13), została po raz pierwszy spełniona, gdy w młodym Kościele powstał spór o obrzezanie (Dz 15,1-2). Wówczas, po wymianie doświadczeń z pracy misyjnej okazało się, że również nieobrzezani otrzymywali Ducha Świętego, bo Bóg „nie zrobił żadnej różnicy między [Apostołami] a nimi, oczyszczając przez wiarę ich serca" (Dz 15,9) $)^{39}$. Dlatego Apostołowie i starsi, zgromadzeni na swym pierwszym „soborze” zwanym jerozolimskim (49/50 r.), wyrazili swe stanowisko w stwierdzeniu: „Postanowiliśmy bowiem, Duch Święty i my, nie nakładać na was żadnego

37 Por. Cyryl Aleksandryjski, In Ioannis Evangelium, V 2; PG 73, kol. 755.

38 DeV 24.

39 Na temat „przekonywania” Piotra przez Ducha Świętego w sprawie nieobrzezanych, zob.: N. Skuras, Posłannictwo trynitarne źródłem misji Kościoła (Dz 10), „Studia Redemptorystowskie" 14 (2016), s. 234-236. 
ciężaru oprócz tego, co konieczne" (Dz 15,28) ${ }^{40}$. Odtąd Apostołowie i ich współpracownicy misyjni „nakazywali im przestrzegać postanowień ( $\tau$ à

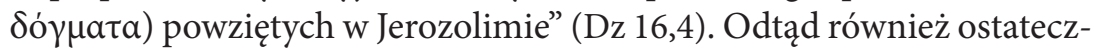
ne rozstrzygnięcia w sprawach wiary i moralności (dogmaty), podejmowane przez Urząd Nauczycielski Kościoła, dokonują się, jak uczy II Sobór Watykański, „przy pomocy Ducha Świętego” ${ }^{41}$.

Innym, na co dzień dostępnym znakiem aktywności Ducha Świętego, są sakramenty. W swej encyklice Dominum et Vivificantem Jan Paweł II zwraca uwagę na eklezjotwórczy aspekt Jego działania: „To nowe przychodzenie Chrystusa za sprawą Ducha Świętego, Jego stała obecność i działanie w życiu duchowym dokonują się w rzeczywistości sakramentalnej. W niej Chrystus, który odszedł w swym widzialnym człowieczeństwie, przychodzi, jest obecny i działa w Kościele w sposób tak wewnętrzny i zespolony, że czyni Kościół swoim Ciałem. Jako Ciało Chrystusa Kościół żyje, działa i wzrasta «aż do skończenia świata». To wszystko dokonuje się za sprawą Ducha Świętego" ${ }^{42}$. Najpełniejszym wyrazem takiego przychodzenia Chrystusa „za sprawą Ducha Świętego" jest, jak podkreśla Jan Paweł II, Eucharystia, za pośrednictwem której „Duch Święty sprawia owo «wzmocnienie sił wewnętrznego człowieka», o którym mowa w Liście do Efezjan (por. Ef 3,16)" oraz objawia istnienie pewnego podobieństwa „między jednością Osób Boskich a jednością synów Bożych zespolonych

${ }^{40}$ Więcej na temat doktrynalnego i prawnego (jurydycznego) znaczenia Soboru (Synodu) Jerozolimskiego, zob.: J. D. SzCzUReK, Jurydyczny wymiar dogmatu, w: P. Majer, A. Wójcik (red.), Lex Tua veritas. Księga pamiątkowa dedykowana Jego Magnificencji Księdzu Profesorowi Janowi Maciejowi Dyduchowi z okazji 70. rocznicy urodzin, Kraków 2010, s. 307-314. Jedną z ostatnich tego typu decyzji podjętych "po wielokrotnym zanoszeniu modłów do Boga i wzywaniu światła Ducha Prawdy” ("postquam supplices etiam atque etiam ad Deum admovimus preces, ac Veritatis Spiritus lumen invocavimus") jest ogłoszenie dogmatu Wniebowzięcia Błogosławionej Dziewicy Maryi przez Piusa XII w 1950 roku. PIUs XII, Konstytucja apostolska Munificentissimus Deus, Rzym 1950, Acta Apostolicae Sedis, 42 (1950), s. 770; por. DS 3903. Tekst polski cytowanego fragmentu: BF VI, 105.

${ }^{41}$ II Soвór WATYKaŃsKi, Konstytucja dogmatyczna o Objawieniu Bożym Dei verbum, Rzym 1965, 10b. „Magisterium non supra verbum Dei est, sed (...) ex divino mandato et Spiritu Sancto assistente (...) fideliter exponit". Constitutio dogmatica de divina revelatione Dei Verbum, Rzym 1965, 10b.

${ }^{42} \mathrm{DeV} 61 \mathrm{~b}$. 
w prawdzie i miłości (KDK 24)”³. O tę jedność Kościół modli się w epiklezie komunijnej ${ }^{44}$. Na przykład w Drugiej modlitwie eucharystycznej czyni to słowami: „Pokornie błagamy, aby Duch Święty zjednoczył nas wszystkich, przyjmujących Ciało i Krew Chrystusa"45. W tym kontekście trzeba z naciskiem podkreślić, że samo dokonanie się Eucharystii również jest dziełem Ducha Świętego, o którego w epiklezie konsekracyjnej ${ }^{46}$ wspomnianej modlitwy eucharystycznej Kościół prosi Ojca: „Uświęć te dary mocą Twojego Ducha, aby stały się dla nas Ciałem i Krwią naszego Pana Jezusa Chrystusa" ${ }^{37}$. Nie należy także zapominać, że gromadzenie się Ludu Bożego na sprawowanie Eucharystii również jest dziełem Ducha Świętego, „który gromadzi dzieci Boże w jednym Kościele Chrystusa" ${ }^{\prime \prime}$ dając im tym samym „przystęp do Ojca” (por. Ef 2,18). W ten sposób Duch Święty buduje wspólnotę dzieci Bożych zgodnie z nauką św. Pawła: „wszyscy ci, których prowadzi Duch Boży, są synami Bożymi” (Rz 8,14).

\section{Celowość posłania}

Szukając odpowiedzi na pytanie o celowość posłania Syna na świat, musimy uwzględnić przede wszystkim następujące stwierdzenie Boże-

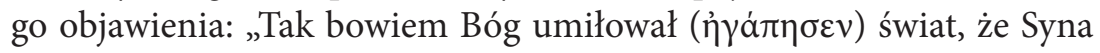
swego Jednorodzonego (...) posłał (ả $\left.\dot{a}_{\varepsilon} \sigma \tau \varepsilon \iota \lambda \varepsilon v\right)$ (...) na świat po to, aby (...) świat został przez Niego zbawiony (iv $\sigma \omega \theta \tilde{n})$ ” (J 3,16-17). W tym krótkim zdaniu powstałym z połączenia dwu kolejnych wierszy wyrażony jest motyw posłania, fakt posłania i jego cel. Motywem posłania jest

${ }^{43}$ DeV 62a.

44 Epikleza komunijna jest to „modlitwa do Boga Ojca o zesłanie Ducha Świętego (...) na uczestników liturgii eucharystycznej celem ich zjednoczenia i uświęcenia”. K. STANIECKI, Epikleza, w: Ł. Bieńkowski, W. Granat, F. Gryglewicz, M. Krąpiec, R. Łukaszyk (red.), Encyklopedia katolicka, t. 4, kol. 1028.

${ }^{45}$ Mszał Rzymski dla diecezji polskich, Poznań 2010, s. 318*. Por. KKK 1108-1109.

${ }^{46}$ Epikleza konsekracyjna jest to „modlitwa do Boga Ojca o zesłanie Ducha Świętego na dary ofiarne w celu ich przeistoczenia”. K. STANIECKI, Epikleza..., dz. cyt., kol. 1028.

${ }^{47}$ Mszał Rzymski..., dz. cyt., s. 316*. Por. KKK 1105-1107.

${ }^{48}$ KKK 1097. 


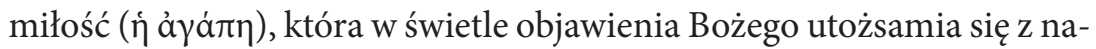
turą Bożą (por. $1 \mathrm{~J}$ 4,8.16). Fakt posłania jest wyrażony czasownikiem w czasie przeszłym dokonanym, ale nieokreślonym co okresu trwania (czyli w aoryście), co w tym przypadku można interpretować, jak się wydaje, jako czynność jednorazową. Wreszcie celem posłania jest zbawienie ( $\sigma \omega \tau \eta \rho i ́ a)$. Oznacza ono przebogatą rzeczywistość nadprzyrodzoną, której „serce człowieka nie [zdoła] pojąć” (1 Kor 2,9), a która może być opi-

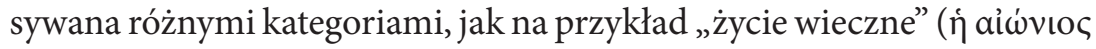

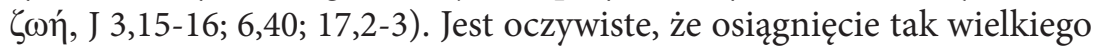
celu wymaga odpowiednich środków. Publiczna działalność Jezusa z Nazaretu, Jego czyny i nauczanie (por. Dz 1,1), ukazuje Jego drogę do celu i równocześnie sposoby naszego uczestnictwa w niej, na przykład wzięcie krzyża i naśladowanie Go (por. Mk 8,34).

Na początku swej publicznej działalności w synagodze w Nazarecie Jezus opisał cel swego posłannictwa słowami proroka Izajasza: „Duch Pański (...) namaścił i posłał Mnie, abym ubogim niósł dobrą nowinę, więźniom głosił wolność, a niewidomym przejrzenie; abym uciśnionych odsyłał wolnymi, abym obwoływał rok łaski od Pana” (Łk 4,18-19). Swe posłannictwo realizuje więc przez głoszenie Ewangelii, uzdrawianie i uświęcanie, uwalniając spotkanych ludzi od różnych zniewoleń egzystencjalnych.

Do faktu bycia posłanym przez Ojca Jezus wielokrotnie nawiązywał, wskazując równocześnie cele cząstkowe, pozwalające zrealizować cel główny. W podsumowaniu swej nauczycielskiej działalności stwierdza: „Nie mówiłem bowiem sam od siebie, ale Ten, który Mnie posłał, Ojciec, On Mi nakazał, co mam powiedzieć i oznajmić (...). To, co mówię, mówię tak, jak Mi Ojciec powiedział” (J 12,49-50). W ten sposób nawiązuje do funkcji nauczycielskiej (por. Mt 23,8) powierzonej Mu przez Ojca. Ścisłą więź między Nim jako posłanym i Ojcem jako posyłającym widać jeszcze wyraźnej w innej Jego wypowiedzi: „kto Mnie przyjmuje, przyjmuje Tego, który Mnie posłał" (J 13,20; por. 17,21).

W celowości zbawczego posłannictwa mieści się także funkcja uświęcająca, która jest realizowana przez odpuszczanie grzechów. O posiadaniu takiej władzy Jezus przekonał swoich uczniów, gdy zauważył, że do paralityka „łatwiej powiedzieć: "Odpuszczają ci się twoje grzechy»", 
niż „powiedzieć: «Wstań i chodź!»” (Mt 9,5). On jest w stanie równie skutecznie „powiedzieć” jedno i drugie. Tę władzę odpuszczania grzechów Jezus Chrystus przekazał Apostołom w dniu swego zmartwychwstania: " "Jak Ojciec Mnie posłał, tak i Ja was posyłam». Po tych słowach tchnął na nich i powiedział im: «Weźmijcie Ducha Świętego! Którym odpuścicie grzechy, są im odpuszczone, a którym zatrzymacie, są im zatrzymane»" (J 20,21-23). Przekazywanie ludziom uczestnictwa w świętości Boga należy do funkcji kapłańskiej w sensie ścisłym (węższym). Należy do niej również, a właściwie to przede wszystkim, składanie ofiar. Również w tym celu został posłany Syn Boży wcielony: Bóg Ojciec „sam nas umiłował i posłał Syna swojego jako ofiarę przebłagalną za nasze grzechy" (1 J 4,10). Przed ostatecznym dokonaniem się ofiary krzyżowej, a po uroczystym wjeździe do Jerozolimy Jezus wyznaje: „Teraz dusza moja doznała lęku i cóż mam powiedzieć? Ojcze, wybaw Mnie od tej godziny. Nie, właśnie dlatego przyszedłem na tę godzinę" (J 12,27), a tą godziną był czas męki i śmieci krzyżowej (por. J 19,27) ${ }^{49}$. Składanie Bogu ofiar jest wyrazem kultu, który może przybierać różne formy. Istotne jednak jest, aby to był kult, jakiego Bóg oczekuje: „Bóg jest duchem: potrzeba więc, by czciciele Jego oddawali Mu cześć w Duchu i prawdzie" (J 4,24). Gdy Samarytanka wyraziła nadzieję na objawienie prawd dotyczących prawdziwego kultu przez oczekiwanego Mesjasza, Jezus jej odpowiedział: "Jestem nim Ja, który z tobą mówię" (J 4,26). On jest więc tym, który objawia wszystko, także i to, „gdzie należy czcić Boga” (J 4,20).

W dyskusji podczas uroczystości poświęcenia świątyni Jezus wyjaśnił Żydom, że Ojciec dał Mu owce (J 10,29), za które On oddaje swe życie jako Dobry Pasterz (J 10,11) i którym On daje „życie wieczne. Nie zginą one na wieki i nikt nie wyrwie ich z [Jego] ręki” (J 10,28). Funkcja pasterska jest funkcją przywódczą, kierowniczą, jest nią również funkcja królewska. Również w celu wypełnienia takiej funkcji posłał Ojciec swego Syna: „Posłał swe słowo synom Izraela, zwiastując im pokój przez

49 J. Galot wprost stwierdza, że Ojciec posłał na śmierć swego Syna jedynego („Le Père qui envoie à la mort son Fils unique”). Por. J. Galot, Notre Père qui est amour, Saint Maur 1998, s. 100-103. 
Jezusa Chrystusa. On to jest Panem wszystkich" (Dz 10,36) i Królem, ale Jego „Królestwo (...) nie jest $z$ tego świata” (J 18,36).

To wszystko, co o sposobie realizacji dzieła zbawczego zostało pobieżnie zasygnalizowane, II Sobór Watykański streścił w następującym stwierdzeniu dotyczącym katolickości Ludu Bożego: „Na to bowiem posłał Bóg Syna swego, którego ustanowił dziedzicem wszystkich rzeczy (por. Hbr 1,2), aby był Nauczycielem, Królem i Kapłanem wszystkich, Głową nowego i powszechnego ludu synów Bożych"50. Jest to bardzo wyraźne stwierdzenie celu posłania ujętego w troistą funkcję mesjańską (triplex munus, różnie nazywaną): prorocką/nauczycielską, ofiarniczą/uświęcającą/kultyczną, królewską/kierowniczą/pasterską. Tradycyjnie jest ona opisywana w następującej kolejności: prorocka, kapłańska i królewska. Często jest też prezentowana jako trzy funkcje mesjańskie (tria munera). W innym miejscu (w nauce o biskupach) Sobór stwierdza: „Zatem w osobach biskupów (...), obecny jest wśród wiernych Pan Jezus Chrystus, Kapłan Najwyższy. Siedząc bowiem po prawicy Ojca, przebywa równocześnie w zgromadzeniu swoich biskupów i za pośrednictwem przede wszystkim ich zaszczytnej służby słowo Boże głosi wszystkim narodom, a wiernym udziela sakramentów wiary (...), za pomocą wreszcie ich mądrości i roztropności prowadzi i kieruje lud Nowego Testamentu w jego wędrówce do szczęśliwości wiecznej”51 . Różnica między oboma stwierdzeniami polega na tym, że drugie wyraźnie przypisuje Chrystusowi jako kapłanowi wspomnianą troistą funkcję, co oznacza, że kapłaństwo Chrystusa jest tu rozumiane szeroko. Takie zresztą rozumienie kapłaństwa służebnego (urzędowego) występuje w soborowej nauce o kapłaństwie powszechnym i służebnym: „Kapłan urzędowy mianowicie, dzięki władzy świętej, jaką się cieszy, kształci lud kapłański i kieruje nim, sprawuje w zastępstwie Chrystusa (in persona Christi) Ofiarę eucharystyczną i składa ją Bogu w imieniu całego ludu" ${ }^{2}$. „Kształcenie” nawiązuje do funkcji nauczycielskiej, ,kierowanie” - do funkcji pasterskiej (królewskiej), a „sprawowanie Ofiary” - do funkcji kultycznej (kapłańskiej w sensie węższym).

\footnotetext{
50 LG 13a.

51 LG 21a.

52 LG 10b.
} 
Jeśli wspomnianą troistą funkcję mesjańską (kapłańską) potraktujemy rozłącznie, możemy każdej z nich przypisać właściwy jej aspekt soteriologiczny, czyli określić, w jaki sposób jej realizacja służy zbawieniu człowieka. Tak więc wypełniając funkcję nauczycielską, Jezus dokonał pojednania ludzi z Bogiem Ojcem przez objawienie prawdy o Bogu i o człowieku. Jest On więc najwyższym i jedynym nauczycielem wszystkich ludzi (por. Mt 23,8; J 13,13). Nauczanie jest czynnością zbawiającą, ponieważ nieznajomość Boga albo błędne pojęcie o Nim, jest następstwem grzechu. Grzech zaś wraz ze śmiercią wszedł na świat przez zawiść diabła, który jest ojcem kłamstwa (J 8,44; Rz 1,18-20; por. J 1,5; 3,19; Mdr 2,24). Poprzez swe nauczanie Chrystus oddziałuje na umysł człowieka, poszerzając jego wiedzę o Bogu i o Nim samym. Jednym z celów Jego przyjścia na świat jest właśnie zniszczenie dzieła diabła (1 J 3,8), który na początku dziejów podstępem skłonił ludzi do nieposłuszeństwa Bogu (Rdz 3,1-7), czyniąc ich swymi niewolnikami (poddanymi, Łk 4,6). Chrystus jest więc nauczycielem wyzwalającej prawdy (J 8,32), której On sam jest uosobieniem (J 14,6). Słusznie więc II Sobór Watykański na przykład w Dekrecie o posłudze i życiu kapłanów uczy, że „prezbiterzy osiągną świętość", jeśli już „w samym momencie przekazywania słowa będą się łączyć z Chrystusem Nauczycielem i pozwolą się prowadzić Jego Duchem" 53 .

Następnie, realizacja funkcji ofiarniczej (kapłańskiej w sensie węższym) jest centralnym działaniem zbawczym. Bardzo obszernie mówi o tym List do Hebrajczyków, który jest poświęcony kontemplacji ofiary Chrystusa i związanego z nią Jego kapłaństwa. Autor Listu wykazuje jego wyższość ponad wszelkie inne formy kapłaństwa. Jako najwyższy kapłan Chrystus spełnia wszystkie warunki doskonałego kapłaństwa: składa jedyną doskonałą ofiarę (ze siebie) za grzechy (Hbr 5,1; 7,27; 9,28); jest prawdziwym człowiekiem „,z ludzi wziętym” (Hbr 5,1) i jako człowiek jest kapłanem „na wzór Melchizedeka” (Hbr 5,6); jako człowiek jest również z ludźmi solidarny (Hbr 4,15); powstawszy z martwych nie potrzebuje ponawiać swej ofiary - „ma kapłaństwo nieprzemijające”

${ }^{53}$ II Soвór Watykański, Dekret o posłudze i życiu prezbiterów Presbyterorum ordinis, Rzym 1965 (dalej: PO) 13a.b. 
(Hbr 7,24); jako kapłan jest On również pośrednikiem (Hbr 8,6; 9,15; $12,24 ; 1 \mathrm{Tm} 2,5)$. Znaczenie zbawcze ofiary wynika zatem przede wszystkim stąd, że jako akt kultu jest uznaniem Boga za najwyższą wartość, uwielbia Go i jednoczy człowieka z Nim. W świetle nauczania II Soboru Watykańskiego „prezbiterzy łączą się z czynnością Chrystusa kapłana”, gdy „,w ofierze Mszy Świętej zastępują w specjalny sposób osobę Chrystusa, który dał samego siebie jako żertwę ofiarną dla uświęcenia ludzi" oraz gdy „siebie całych codziennie ofiarują Bogu” ${ }^{54}$.

Wreszcie, wykonywanie funkcji pasterskiej (kierowniczej) prowadzi do zbawienia poprzez wskazywanie ludziom celu ostatecznego, jakim jest życie wieczne. Jego osiągnięcie uniemożliwia grzech, który oznacza błądzenie, zejście na bezdroża. Funkcja pasterska jest zatem skierowana przede wszystkim ku woli człowieka, mobilizując ją do posłuszeństwa Bożym przykazaniom. Funkcję tę Chrystus realizował na różne sposoby przez: nadawanie przykazań (J 13,34; 15;12 - przykazanie miłości) i wymaganie ich przestrzegania (J 14,15; 15,10; Mt 28,20); wykonywanie władzy sądzenia (J 5,22; Mt 25,46), ustanawianie na ziemi królestwa Bożego i ogłaszanie jego przyjścia (Mk 1,15; Łk 8,1). Królestwo Chrystusa nie jest $\mathrm{z}$ tego świata (J 18,36; por. J 6,15; Mt 22,21), a Jego władza rozciąga się na całą rzeczywistość: niebo i ziemię (Mt 28,18; por. J 1,5; 19,16). Według nauki II Soboru Watykańskiego prezbiterzy ,jako rządcy wspólnoty pielęgnują ascezę", szukając tego, „co służy wszystkim, aby byli zbawieni” ${ }^{55}$.

\section{Uczestnictwo i naśladowanie}

Gdy Jezus ukazał się uczniom w dniu swego zmartwychwstania, „rzekł

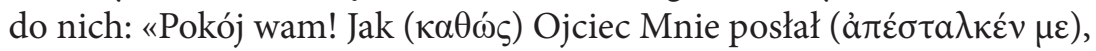
tak i Ja was posyłam $(\pi \varepsilon \dot{\mu} \mu \pi \omega) » "(J$ 20,21). Z perspektywy misyjnej Kościoła to zdanie wyraża bardzo istotne kwestie: stwierdza posłanie Jezusa przez Ojca, posłanie przez Ojca jest wzorem posłania uczniów, uczniowie są posłani bezpośrednio przez samego Jezusa. Posłanie przez Jezusa

\footnotetext{
54 PO 13c.d.

55 PO 13e.
} 
oznacza, że On działa tak jak Ojciec i jako Jemu równy. Tu już nie powołuje się na „widzenie” Ojca czyniącego (por. J 5,19), lecz czyni to własną mocą jako już wywyższony przez Ojca (por. Flp 2,9). Może tak czynić, ponieważ „dana $[\mathrm{Mu}]$ została wszelka władza w niebie i na ziemi” $(\mathrm{Mt} 28,18)$. Użycie innego słowa greckiego $(\pi \varepsilon ́ \mu \pi \omega)$ na oznaczenie posłania uczniów nie wydaje się mieć jakiegoś szczególnego znaczenia, ponie-

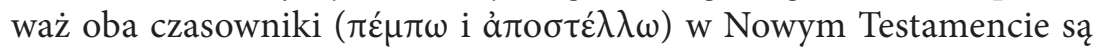
użyte do wyrażenia czynności Boga ${ }^{56}$, przy czym ảંooté $\lambda \lambda \omega$ występuje prawie dwa razy częściej5. Warto jednak zauważyć, że $\pi \varepsilon ́ \mu \pi \omega$ oprócz „posyłać”, „wysyłać" może także oznaczać „,wyprawiać" 58 , co wskazuje na pewne wyposażenie posyłanego, które potrzebne jest do wykonania zlecanego mu zadania. Przykładem takiego „wyposażenia” jest władza odpuszczania grzechów (J 20,22).

Odwołanie się do podobieństwa między posłaniem Syna przez Ojca i uczniów przez Syna przy użyciu słowa „jak” ( $\alpha a \theta \omega ́ \varsigma)$ w znaczeniu „podobnie jak", „(tak) jak" ${ }^{29}$ zakłada ich uczestnictwo w Jego posłannictwie, a szczególnie $\mathrm{w}$ celowości tego posłania i w wyposażeniu koniecznym do jego realizacji. Świadomość bycia posłanymi towarzyszyła Apostołom od samego początku i pozwalała im określić kierunki apostołowania. Widać to na przykład w relacji św. Pawła zawartej w Liście do Galatów, gdzie autor relacjonuje uzgodnienia między nim a św. Piotrem: „uznawszy daną mi łaskę, Jakub, Kefas i Jan, uważani za filary, podali mnie i Barnabie prawicę na znak wspólnoty, byśmy szli do pogan, oni zaś do obrzezanych, byleśmy pamiętali o ubogich, co też gorliwie starałem się czynić" (Ga 2,9-10). Łaska dana Pawłowi jest to współdziałanie Boga w apostołowaniu - została dana wpierw „filarom” Kościoła jerozolimskiego. Współdziałanie Boga odnosi się przede wszystkim do działania Ducha Świętego, który sprawiał cuda wśród ochrzczonych (por. Ga 3,5), inspirował Piotra w mowie do Sanhedrynu (Dz 4,8), zstąpił na domow-

${ }^{56}$ Por. R. Popowski, Wielki słownik..., dz. cyt., n. 641 (II2a), n. 3868 (2b).

57 Por. tamże, à czasowniki tłumaczy przez „mitto”.

58 Tamże, n. 3868.

59 Tamże, n. 2520. 
ników Korneliusza podczas przemówienia św. Piotra (Dz 10,44), wybrał Szawła (Pawła) i Barnabę do przeznaczonego dla nich dzieła (Dz 13,2), objawił swoją wolę podczas tzw. Soboru Jerozolimskiego (Dz 15,28). Te kilka przykładów wskazuje na bardzo dynamiczne zaangażowanie Ducha Świętego w pierwsze działania misyjne Kościoła, co równocześnie potwierdza podobieństwo posłania uczniów do posłania Syna wcielonego i namaszczonego Duchem Świętym.

We współczesnym nauczaniu Kościoła o posłaniu misyjnym akcent jest położony na uczestnictwo w posłannictwie Jezusa Chrystusa. Dotyczy ono najpierw całego Kościoła, co podkreśla Katechizm Kościoła katolickiego: „Posłanie Chrystusa i Ducha Świętego wypełnia się w Kościele, Ciele Chrystusa i Świątyni Ducha Świętego. To wspólne posłanie (missio coniuncta) włącza już idących za Chrystusem do Jego komunii z Ojcem w Duchu Świętym: Duch przygotowuje ludzi, uprzedza ich swoją łaską, aby pociągnąć ich do Chrystusa"60.

To „wspólne posłanie” realizowane jest właśnie poprzez podstawowe formy uczestnictwa w kapłaństwie Chrystusa i realizację jego troistej funkcji. Tak więc w świetle nauczania II Soboru Watykańskiego wszyscy ochrzczeni „poświęcani są przez odrodzenie i namaszczenie Duchem Świętym, jako dom duchowy i święte kapłaństwo" ${ }^{61}$, które jest realizowane jako kapłaństwo powszechne wiernych (sacerdotium commune fidelium). Dzięki niemu „Najwyższy i przedwieczny Kapłan Jezus Chrystus, pragnąc, aby Jego świadectwo i Jego posługa trwały nieprzerwanie także za pośrednictwem ludzi świeckich, ożywia ich Duchem swoim i nieustannie zachęca do wszelkiego dzieła szlachetnego i doskonałego" ${ }^{2}$. Dlatego „Wszyscy wierni stają się świętym i królewskim kapłaństwem, składają Bogu duchowe ofiary przez Jezusa Chrystusa i głoszą wspaniałe dzieła Tego, który ich wezwał z ciemności do przedziwnego swojego światła” oraz udzielił im tej władzy, „aby i oni posiedli stan królewskiej wolności i przez zaparcie się siebie oraz przez życie święte pokonywali
60 KKK 737.
61 LG 10a.
${ }^{62}$ LG 34. 
w sobie samych panowanie grzechu (por. Rz 6,12)"63. Tak dobrana kompilacja tekstów soborowych pokazuje wyraźnie troisty charakter kapłańskiego posłannictwa wynikającego z ,odrodzenia i namaszczenia Duchem Swiętym”, czyli z sakramentów chrztu i bierzmowania: „głoszenie «wspaniałych dzieł» Bożych" (funkcja prorocka), ,składanie Bogu duchowych ofiar" (funkcja kultyczna [kapłańska w znaczeniu węższym]) i „pokonywanie w sobie samych panowania grzechu” (funkcja królewska).

Drugą formą uczestnictwa w kapłaństwie Chrystusa jest „kapłaństwo urzędowe, czyli hierarchiczne" (sacerdotium ministeriale seu hie$\operatorname{rarchicum}^{64}$ ), albo służebne, przekazywane przez sakrament święceń ( $s a$ cro Ordine) tym, którzy „ustanawiani są w imię Chrystusa, aby karmili Kościół słowem i łaską Bożą" ${ }^{65}$. W świetle soborowej nauki o sakramencie święceń istnieją jego trzy stopnie: „Tak oto urząd kościelny (ministerium ecclesiasticum), przez Boga ustanowiony, sprawowany jest w różnych stopniach święceń (diversis ordinibus exercetur) przez tych, którzy od starożytności już noszą nazwę biskupów, prezbiterów i diakonów" ${ }^{\prime 66}$. Wewnętrzne relacje istniejące między tymi stopniami zwięźle opisuje Katechizm Kościoła katolickiego: „zarówno dwa stopnie uczestniczenia (gradus participationis) w kapłaństwie (episkopat i prezbiterat), jak i stopień służby (gradum servitii, diakonat), są udzielane za pośrednictwem aktu sakramentalnego nazywanego «święceniami», to znaczy przez sakrament święcen'" ${ }^{\prime \prime}$.

W świetle Konstytucji Lumen gentium za pośrednictwem biskupów działa wśród wiernych sam „Pan Jezus Chrystus, Kapłan Najwyższy", który siedząc po prawicy Ojca, za ich pośrednictwem głosi słowo Boże, udziela sakramentów wiary i prowadzi Lud Boży do szczęśliwości wiecznej ${ }^{68}$. Prezbiterzy zaś, w świetle tej samej Konstytucji, „na mocy

\footnotetext{
${ }^{63}$ LG 36a.

${ }^{64} \mathrm{LG} 10 \mathrm{~b}$.

65 LG 11 b.

${ }^{66}$ LG 28a.
}

${ }^{67}$ KKK 1554. Więcej o stopniach święceń w nauczaniu II Soboru Watykańskiego, zob.: J. D. Szczurek, Sakrament święceń, w: K. Porosło, R. J. Woźniak (red.), Znaki Tajemnicy. Sakramenty w teorii i praktyce Kościoła, Kraków 2018, s. 467-474.

${ }^{68}$ LG 21. 
sakramentu kapłaństwa, na podobieństwo Chrystusa, najwyższego i wiekuistego Kapłana (Hbr 5,1-10, 7,24, 9,11-28), wyświęcani są, aby głosić Ewangelię, być pasterzami wiernych i sprawować kult Boży jako prawdziwi kapłani Nowego Testamentu”69. Wreszcie diakoni, „stosownie do tego, co [im] wyznaczy kompetentna władza"70, udzielają sakramentu chrztu świętego, pełnią posługę przy innych sakramentach (Eucharystia, małżeństwo), czytają wiernym Pismo Święte i napominają ich oraz przewodniczą nabożeństwu i modlitwie wiernych ${ }^{71}$. Łatwo zauważyć, że każdy stopnień święceń jest realizowany poprzez wypełnianie troistej funkcji (albo trzech funkcji) posłannictwa Chrystusa: nauczania, uświęcania i kierowania. Równocześnie należy zauważyć, że w zależności od stopnia święceń poszczególne elementy tej funkcji różnie są akcentowane, co widać także w kolejności ich wymieniania.

To wszystko, co dotyczy uczestnictwa w kapłańskim posłannictwie Jezusa Chrystusa, odnosi się także do misjonarzy i to nie tylko duchownych, ale i wszystkich innych: kapłanów, braci, sióstr i świeckich ${ }^{72}$. Oni bowiem otrzymują charyzmat misyjny dzięki zaangażowaniu Ducha Świętego w ścisłym zjednoczeniu z wcielonym Synem Bożym. W Dekrecie Ad gentes II Sobór Watykański podkreśla analogię między działaniem Ducha Świętego w Chrystusie Jezusie, który przez Niego „wprowadzony został w swe dzieło" (por. Łk 3,22; 4,1; Dz 10,38) ${ }^{73}$, a Kościołem, którego On ,jednoczy we wspólnocie i w posłudze i uposaża go w rozmaite dary hierarchiczne oraz charyzmatyczne (...) wsączając do serc wiernych tego samego ducha misyjnego, jakim wiedziony był sam Chrystus"74.

Zgodnie z nauką zawartą we wspomnianym Dekrecie Ad gentes misjonarz „posłuszny razem z Chrystusem woli Ojca, poprowadzi dalej Chrystusowe dzieło pod hierarchicznym zwierzchnictwem Kościoła i będzie współpracował w tajemnicy zbawienia"75. Zatem głównym celem

\footnotetext{
69 LG 28a.

${ }^{70}$ LG 29.

71 Por. LG 29.

72 Por. DM 23b. 26 b.

73 DM 4.

74 DM 4; por. LG 4.

75 DM 25.
} 
działalności każdego misjonarza jest zbawienie tych, którym służy. W konsekwencji jego nauczanie, sprawowanie kultu i kierowanie wspólnotą podporządkowane ma być temu właśnie celowi. Jak Chrystus Jezus ustanowił swój Kościół ${ }^{76}$ ze względu na ten właśnie cel, tak misjonarze jako „współpracownicy Boga” mają za zadanie tworzyć wspólnoty wiernych, które „wykonywałyby zadanie zlecone im przez Boga, a mianowicie zadanie kapłańskie, nauczycielskie i pasterskie. W ten sposób wspólnota chrześcijańska staje się znakiem obecności Bożej w świecie" 77 . Tak więc posłannictwo misjonarzy realizowane jest na podobieństwo posłannictwa Chrystusa w jedności z Duchem Świętym.

O współdziałaniu Ducha Świętego w działalności misyjnej Sobór mówi we wspomnianym Dekrecie, w paragrafie poświęconym Ludowi Bożemu. Jest On wewnętrzną zasadą życia wspólnotowego wiernych Kościoła ${ }^{78}$, głównym „Bohaterem” (Protagonist) trynitarnego posłannictwa w Kościele ${ }^{79}$. To bycie zasadą wyraża się głównie przez to, że „Duch Święty (...) gromadzi ich w jeden Lud Boży, który jest «rodzajem wybranym, królewskim kapłaństwem, narodem świętym, ludem nabytym» (1 P 2,9)"80. Czyni to szczególnie wówczas, gdy głoszona jest Ewangelia i udzielany jest chrzest święty. To właśnie On jest tym, który „wzywa wszystkich ludzi do Chrystusa i budzi w sercach posłuszeństwo wierze"s1. Tak Duch Święty „,niesie” Chrystusa tym, do których skierowana jest posługa misyjna. Aktualne wspieranie działalności misyjnej przez Ducha Świętego jest kontynuacją Jego współdziałania podczas publicznej działalności Chrystusa, a potem w początkach Kościoła, o czym wspomniano wyżej. Z punktu widzenia pneumatologii na szczególną uwagę zasługuje fragment Dekretu poświęcony zbawczemu zaangażowaniu Trójcy

76 Por. LG 3.5.

77 DM 15b.

78 Por. S. Brechter, Dekret über die Missionstätigkeit der Kirche [Einleitung und Kommentar], LThK 14, s. 59.

79 Por. L. SiweCKI, Trinity and Church in the Light of Vatican II's Constitution «Lumen Gentium», „Roczniki Teologiczne” 2(62) (2015), s. 168.

80 DM 15a.

${ }^{81}$ DM 15a. 
Świętej ${ }^{82}$, gdzie Sobór stwierdza, że Chrystus posłał „od Ojca Ducha Świętego, by przeprowadzał zbawcze Jego dzieło od wewnątrz (intus) i pobudzał Kościół do rozszerzania się" ${ }^{\text {"3 }}$. Następnie uzasadnia je, odwołując się m.in. do wspomnianego już działania Ducha Świętego w życiu Jezusa Chrystusa („z chwilą zstąpienia Ducha Świętego na Najświętszą Maryję Pannę począł się Chrystus”, „wprowadzony został w swe dzieło" ${ }^{44}$ ). Ponadto na uwagę zasługuje podkreślenie działania Ducha Świętego „od wewnątrz”, czyli „przez serce” każdego pojedynczego wierzącego, a w tym przypadku każdego misjonarza. Jest to więc działanie bardzo zindywidualizowane, dostosowywane do konkretnych warunków misyjnych, co od strony misjonarza wymaga wrażliwości na natchnienia Ducha Świętego, postawy posłuszeństwa, a także - o czym również nie można zapominać - umiejętności rozpoznawania duchów.

Oprócz tych zasadniczych działań Ducha Świętego Dekret mówi jeszcze o innych formach Jego aktywności w Kościele i w świecie, jak na przykład: poprzez działalność misyjną Duch Święty scala Lud Boży w swej jednej świątyni i odradza go w Chrystusie ${ }^{85}$, umacnia wierzących w Chrystusa w sakramencie bierzmowania ${ }^{86}$, otwiera serca niechrześcijan na wiarę i sprawia ich dobrowolne nawrócenie się do Pana ${ }^{87}$, przez sakramenty wtajemniczenia czyni ich przybranymi synami Bożymi ${ }^{88}$, ,wzbudza w sercach jednostek powołanie misyjne, a równocześnie w Kościele powołuje do życia instytuty [misyjne]"89, uzdalnia do odpowiedzi na Boże wezwanie do ofiary z siebie na wzór Chrystusa ${ }^{90}$, ,w wieloraki sposób pobudza ducha misyjnego w Kościele Bożym" ${ }^{\text {"1 }}$ z J Jego natchnienia

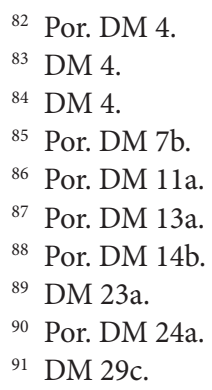


„stale rozwijają się w Kościele coraz bardziej instytuty świeckie"92, Sobór pragnie, aby dzięki działalności misyjnej światłość Boża „olśniła wszystkich przez Ducha Świętego" ${ }^{93}$.

„Niesienie" Chrystusa przez Ducha Świętego współczesnemu światu jest możliwe dzięki osobistemu zaangażowaniu tych, którzy pozytywnie odpowiadają na Boże wezwanie. Powołanie misyjne jest szczególnym charyzmatem związanym $\mathrm{z}$,odpowiednimi naturalnymi właściwościami, przymiotami serca i umysłu" ${ }^{\prime 4}$. Dlatego rozpoznanie konkretnego powołania misyjnego i odpowiednie ukształtowanie go należy nie tylko do samego powołanego, ale także do jego właściwego przełożonego ${ }^{95}$. Misjonarz bowiem jest posyłany przez prawowitą władzę, aby z wiarą i posłuszeństwem być sługą Ewangelii ${ }^{96}$. W tym właśnie posłuszeństwie biskupowi jest podobieństwo do Chrystusa posłusznego Ojcu. Dlatego jednym z najważniejszych "przymiotów serca i umysłu misjonarza” jest zdolność do wyrzeczenia się wszystkiego, aby być w stanie wypełnić „posłannictwo Tego, który «wyniszczył samego siebie, przyjąwszy naturę sługi» (Flp 2,7)"997. Równocześnie taka postawa upodabnia „do Chrystusa, najwyższego i wiekuistego Kapłana (Hbr 5,1-10, 7,24, 9,11-28)"98, który „przez Ducha wiecznego złożył Bogu samego siebie jako nieskalaną ofiarę" (Hbr 9,14). Upodabnia go już na poziomie kapłaństwa powszechnego, a w przypadku kapłaństwa służebnego „wyposaża” go w moc odpuszczania grzechów i sprawowania pozostałych sakramentów. Chrystus jest więc „wzorem misjonarza” jako składający ofiarę z samego siebie, czyli jako kapłan w sensie węższym (choć w samym akcie ofiarowania siebie jest aspekt nauczycielski poprzez danie przykładu oraz aspekt królewski poprzez „królewską wolność” w oddaniu życia).

Możliwość upodabniania się do Jezusa Syna Bożego zasadza się na tajemnicy Wcielenia: On jest „wzorem misjonarza” jako Syn wcielony.
${ }_{92} \mathrm{DM} 40 \mathrm{~d}$.
93 DM 42b.
${ }^{94}$ DM 23a-b.
95 Por. DM 24c.
96 Por. DM 23b.
97 DM 24a.
98 LG 28. 
Wcielenie za sprawą Ducha Świętego oznacza wejście w konkretną ludzką historię w konkretnym miejscu i czasie ${ }^{99}$, co oczywiście wymusza podejmowanie określonych działań czyniących zrozumiałym realizowane posłannictwo. Samo Wcielenie i płynąca zeń nauka jest więc objawieniem się Boga na sposób ludzki. Podobnie misjonarz w swej działalności misyjnej musi uwzględniać specyfikę społeczności, do której się udaje. Słusznie więc Sobór wymaga od misjonarzy wiedzy „o narodach, o ich kulturach i religiach, i to odnośnie nie tylko do przeszłości, lecz i do czasów obecnych”, aby umieli uszanować ich „spuściznę narodową, [ich] język i obyczaje"100. Tu otwiera się szeroka problematyka inkulturacji, którą nie sposób się teraz zajmować ${ }^{101}$. Na mocy Wcielenia Chrystus jest wzorem misjonarza przez swe człowieczeństwo, które jest warunkiem bycia kapłanem (por. Hbr 5,1).

Kapłaństwo Chrystusa, jak to już wyżej zostało zaakcentowane, jest też pojmowane w sensie szerokim, obejmującym obok funkcji kultycznej także nauczycielską i kierowniczą. Chrystus jest więc „wzorem misjonarza” najpierw jako nauczyciel. Jest nauczycielem „drogi Bożej”, której w prawdzie naucza (Mt 22,16). Niekiedy jednak „drogi Boże” krzyżują się z ludzkimi. Przykładem może być odpowiedź na pytanie o płacenie podatków Cezarowi (Mt 22,21). Podobnie misjonarz za cel główny swej działalności ma nauczanie „drogi Bożej” w prawdzie, która wyzwala (por. J 8,32), niemniej jednak jego wiedza w sprawach doczesnych może wiele pomóc tym, którym służy. Słusznie więc Sobór zachęca do troski o wychowanie „dzieci i młodzieży przez szkoły różnego stopnia, które należy uważać (...) za najwyższej wagi usługę dla ludzi (...), oddaną podnoszeniu godności ludzkiej"102. Jednak głoszenie prawdy wyzwalającej z niewoli grzechu i wszelkiego zła ${ }^{103}$ należy do głównych zadań misjonarza wzorującego się na Chrystusie. Aby móc ją głosić w sposób prze-

\footnotetext{
${ }^{99}$ Por. DM 10.

100 DM 26b.

101 Na temat inkulturacji w misjologii, zob. D. J. Вosch, Oblicza misji chrześcijańskiej. Zmiany paradygmatu w teologii misji, Katowice 2010, s. 472-482.

102 DM 12c.

103 O wyzwoleniu integralnym we współczesnej misjologii, zob.: D. J. Bosch, Oblicza misji..., dz. cyt., s. 467-472.
} 
konujący w specyficznych warunkach misyjnych, konieczna jest odpowiednia formacja: duchowa, moralna, naukowa i pastoralna ${ }^{104}$. Cenną pomocą w pracy misyjnej są „studia misjologiczne, tzn. poznanie nauki i zasad Kościoła dotyczących działalności misyjnej (...), a także poznanie obecnego stanu misji i zarazem metod, które teraz uznaje się za bardziej skuteczne"105. Przygotowanie do pracy misyjnej powinno uwzględniać także aspekt ekumeniczny ${ }^{106}$. Uwzględniwszy te wszystkie okoliczności, Sobór z naciskiem podkreśla, że należy wykorzystać każdą „okazję mówienia o tajemnicy Chrystusowej (...), by człowiek zrozumiał, że uwolniony od grzechu, zostaje wprowadzony w tajemnicę miłości Boga”107.

Chrystus jako „wzór misjonarza” jest, jak to wyżej zostało zasygnalizowane, Dobrym Pasterzem, który zna swoje owce (J 10,15), i królem, którego królestwo nie jest z tego świata (J 18,36), a nawet poniekąd "rząadcą", ustanowionym, aby na czas rozdawał żywność (por. Łk 12,42). Podobnie misjonarz jest takim właśnie „rządcą”, szczęśliwym sługą postawionym nad Jego mieniem (Łk 12,43-44). Dlatego Sobór oczekuje od misjonarzy, aby posiadali „wyszkolenie w zakresie porządnej administracji kościelnej, a nawet ekonomicznej"108, które jest konieczne do sprawnego kierowania powierzoną im wspólnotą wiernych, a także zaradzania potrzebom ubogich (por. Ga 2,10). W swym nauczaniu o organizacji działalności misyjnej Sobór zwraca uwagę na odpowiednie zarządzanie wspólnotami lokalnymi: „pracą głosicieli Ewangelii i pomocą innych wiernych należy tak pokierować i tak je zespolić, aby na każdym polu działalności i współpracy misyjnej «wszystko odbywało się w należytym porządku» $(1 \text { Kor } 14,40)^{\prime \prime 109}$.

Realizacja funkcji kierowniczej „w należytym porządku” zależy od spełnienia określonych warunków zarówno w wymiarze wspólnotowym,

104 Por. DM 16b.25a.

105 DM 26b.

106 DM 16d; por. 15b. Kompendium współczesnej misjologii w ujęciu ekumenicznym (z perspektywy protestanckiej), zob.: D. J. Вosch, Oblicza misji..., dz. cyt., ilość stron: 599.
107 DM 13a-b.
108 DM 16d.
109 DM 28b. 
jak i indywidualnym. Podstawowym warunkiem w wymiarze wspólnotowym jest jedność wszystkich pracowników misyjnych. Sobór wzywa ich do takiej współpracy, aby tworzyli „jednego ducha i jedno serce” (Dz 4,32). Współpracę koordynuje biskup, który jako ośrodek „jedności w apostolskiej pracy diecezjalnej” zachowuje i rozwija „inicjatywę tych, którzy uczestniczą w tym dziele” ${ }^{110}$. „Jeden duch”, „jedność w apostolskiej pracy” i „inicjatywa” pracowników misyjnych są przejawem obecności i działania Ducha Świętego, przez którego wierzący w Chrystusa gromadzą się „w Kościele powszechnym u Ojca”"11. Dlatego dla rozwoju dzieła misyjnego jest niezwykle ważna otwartość na Jego wewnętrzne (indywidualne) działania, będące przecież przejawem Jego wewnątrztrynitarnej tożsamości (o której była mowa wyżej).

Natomiast „należyty porządek” w wymiarze indywidualnym może być zapewniony wówczas, gdy każdy „pracownik misyjny” tak podda się działaniu Ducha Świętego, aby na wzór Chrystusa Arcykapłana właśnie przez Niego siebie samego mógł złożyć Ojcu ,jako nieskalaną ofiarę" (Hbr 9,14). Taka ofiara jest wyrazem pokonania w sobie samym panowania grzechu (por. Rz 6,12), co oznacza realizację funkcji królewskiej, przekazywanej już w sakramencie chrztu świętego ${ }^{112}$, i osiągnięcie osobistego „stanu królewskiej wolności” ${ }^{113}$. Wyrzeczenie się siebie i wolność wewnętrzna wspomagają rozwój cnót szczególnie potrzebnych w pracy misyjnej. Dekret Ad gentes zachęca do rozwijania takich cnót jak: wierność powołaniu, posłuszeństwo (przez które Chrystus „odkupił rodzaj ludzki”), pokora (na wzór „Mistrza, który był cichy i pokornego serca”), ofiarność (przez wyrzeczenie się siebie i wszystkiego, co własne), ubóstwo (które nawet w skrajnej postaci daje radość), odwaga (w mówieniu tego co, konieczne, „nie wstydząc się zgorszenia krzyża”), męstwo (aż do przelania krwi), szczera miłość, cierpliwość, łagodność ${ }^{114}$. Rozwojowi tych cnót oraz otwartości na łaskę Ducha Świętego pomagają dni

\footnotetext{
110 DM 30a-b.

111 LG 2.

112 Por. LG 10 i 36.

113 LG 36.

114 DM 24.
} 
skupienia, które służą wzmacnianiu „ufności do swego powołania” oraz odnowie „w służbie apostolskiej” ${ }^{115}$.

Te i wiele innych przymiotów potrzebnych do wiernego wypełnienia kapłańskiego posłannictwa misyjnego misjonarz może osiągnąć, gdy „przepojony żywą wiarą i niesłabnącą nadzieją, (...) będzie mężem modlitwy”, przeniknięty „duchem mocy, miłości i trzeźwości”"116.

\section{$* * *$}

Jezus z Nazaretu, jednorodzony Syn wcielony, został posłany przez Ojca w Duchu Świętym, aby był „Nauczycielem, Królem i Kapłanem wszystkich"117 i aby w ten sposób zbawił świat (por. J 3,17). Gdy dokonał zleconego Mu dzieła, ,ukazał się jako Pan i Mesjasz, i Kapłan ustanowiony (constitutus) na wieki (por. Dz 2,36, Hbr 5,6; 7,17-21) i Ducha obiecanego przez Ojca wylał na uczniów swoich (por. Dz 2,33)"118. Odtąd zaczęły się „dzieje apostolskie” ${ }^{119}$ i gromadzenie dzieci Bożych „w jednym Kościele Chrystusa” ${ }^{120}$. Odtąd także Duch Święty nieustannie „niesie” światu zmartwychwstałego Chrystusa. Dzięki Ich „wspólnemu posłaniu” przekazywane jest uczestnictwo w kapłaństwie Chrystusa, dzięki któremu Kościół realizuje troistą funkcję Jezusa jako Mesjasza (Chrystusa). Właśnie Chrystus w swym kapłaństwie szeroko pojętym jest wzorem misjonarza, który „niesie” ludziom zbawienie, nauczając ich prawdy o Bogu i o człowieku, uświęcając ich przez sakramenty święte i prowadząc ich jak Dobry Pasterz do domu Ojca (por. J 10,16).

W realizacji misyjnego posłannictwa kluczowa jest otwartość na działanie Ducha Świętego. On jest twórcą trynitarnej jedności zarówno w łonie samej Trójcy Świętej, jak i w Jej zbawczym działaniu. Jako pochodzący od Ojca i Syna równocześnie może być jednym Duchem ich Obu. Dlatego tak istotne jest to, że Duch Święty pochodzi od dwu osób
115 DM 24c.
116 DM 25.
117 LG 13a.
118 LG 5.
119 DM 4.
120 KKK 1097. 
równocześnie: od Ojca i od Syna. Dzięki temu właśnie, mieszkając w sercach ludzi (por. 1 Kor 3,16) może być jednym Duchem ich wszystkich $($ Ef 4,4$)$, może działać w konkretnych osobach i równocześnie „między” nimi, współtworząc „jednego ducha i jedno serce” (Dz 4,32). Stąd wynika także ważny wniosek eklezjologiczny: budowanie wspólnoty zbawionych (gromadzenie rozproszonych przez grzech) nie może być tylko chrystocentryczne, musi być równocześnie pneumatocetryczne, a właściwie to musi być przede wszystkim patrocentryczne i dynamicznie komplementarne: chrystologiczne i równocześnie pneumatologiczne, w którym urząd i charyzmat wzajemnie się przenikają i ze sobą współdziałają, podobnie jak ręce Ojca z Ireneuszowej analogii.

Reasumując więc, można powiedzieć, że tożsamość Posłanego wyraża się w Jego kapłaństwie obejmującym nauczanie, uświęcanie i kierowanie, zaś głównym celem posłania jest zbawienie świata. Historycznie jest ono realizowane przez uczestnictwo w tym kapłaństwie przy współdziałaniu Ducha Świętego, który jest Panem i Ożywicielem (DS 50).

\section{Bibliografia}

Balthasar H. U. von, Teologika. Prawda Boga, t. 2, Kraków 2004.

Balthasar H. U. von, Teologika. Duch Prawdy, t. 3, Kraków 2005.

Baron A., Pietras H. (red.), Dokumenty Soborów Powszechnych, tekst grecki, łaciński, polski, t. 1, 325-787, Kraków 2002, „Źródła Myśli Teologicznej” 24.

Baron A., Pietras H. (red.), Dokumenty Soborów Powszechnych, tekst grecki, łaciński, polski, t. 2, 869-1312, Kraków 2002, „Źródła Myśli Teologicznej” 26.

Baron A., Pietras H. (red.), Dokumenty Soborów Powszechnych, tekst grecki, łaciński, polski, t. 3, 1414-1445, Kraków 2007, „Źródła Myśli Teologicznej” 30.

Bokwa I. (red.), Breviarium fidei. Wybór doktrynalnych wypowiedzi Kościoła, Poznań 2007.

Bosch D. J., Oblicza misji chrześcijańskiej. Zmiany paradygmatu $w$ teologii misji, Katowice 2010.

Brechter S., Dekret über die Missionstätigkeit der Kirche [Einleitung und Kommentar], LThK 14, s. 9-125. 
Cyryl Aleksandryjski, In Ioannis Evangelium, PG 73, kol. 755 (Sources Chrétiennes, 600/2018).

Daugherty K., „Missio Dei”. The Trinity and Christian Missions, „Evangelical Review of Theology" 2(31) (2007), s. 151-168.

Denzinger H., Enchiridion symbolorum definitionum et declarationum de rebus fidei et morum. Kompendium der Glaubensbekenntnisse und kirchlichen Lehrentscheidungen. Lateinisch-Deutsch, Freiburg im Br.-BaselRom-Wien 1999.

Durrwell F.-X., L'Esprit Saint de Dieu, Paris 1983.

Durrwell F.-X., Le Père. Dieu en son mystère, Paris 1987.

Galot J., L'Esprit Saint et la spiration, „Gregorianum” 74 (1993), s. 241-259.

Galot J., Notre Père qui est amour, Saint Maur 1998.

Hilberath B. J., Der Personbegriff der Trinitätstheologie in Rückfrage von Karl Rahner zu Tertullians „Adversus Praxean”, Innsbruck-Wien 1986.

Jan Paweł II, Encyklika Dominum et Vivificantem, Rzym 1986.

Katechizm Kościoła katolickiego, Poznań 1994. Tekst łaciński: Catechismus Catholicae Ecclesiae, Citta del Vaticano 1997.

Łukaszuk T. D., Ty jesteś Chrystus, Syn Boga żywego. Dogmat chrystologiczny w ujęciu integralnym, Kraków 2000.

Mszał Rzymski dla diecezji polskich, Poznań 2010.

Pius XII, Konstytucja apostolska Munificentissimus Deus, Rzym 1950, Acta Apostolicae Sedis, 42 (1950), s. 753-773.

Popowski R., Wielki słownik grecko-polski Nowego Testamentu, Warszawa 1995.

Rahner K., Podstawowy wykład wiary. Wprowadzenie do pojęcia chrześcijaństwa, Warszawa 1987.

Serretti M., Il mistero della eterna generazione del Figlio. Attraverso l'opera di Hans Urs von Balthasar, Roma 1998.

Siwecki L., Trinity and Church in the Light of Vatican II's Constitution «Lumen Gentium», „Roczniki Teologiczne” 2(62) (2015), s. 153-173.

Skuras N., Posłannictwo trynitarne źródłem misji Kościoła (Dz 10), „Studia Redemptorystowskie" 14 (2016), s. 229-239. 
II Sobór Watykański, Dekret o misyjnej działalności Kościoła Ad gentes divinitus, Rzym 1965.

II Sobór Watykański, Dekret o posłudze i życiu prezbiterów Presbyterorum ordinis, Rzym 1965.

II Sobór Watykański, Konstytucja dogmatyczna o Kościele Lumen gentium, Rzym 1964.

II Sobór Watykański, Konstytucja dogmatyczna o Objawieniu Bożym Dei verbum, Rzym 1965.

Staniecki K., Epikleza, w: Ł. Bieńkowski, W. Granat, F. Gryglewicz, M. Krąpiec, R. Łukaszyk (red.), Encyklopedia katolicka, t. 4, kol. 1028-1031.

Szczurek J. D., Bóg Ojciec w tajemnicy Trójcy Świętej. Elementy patrologii, Kraków 2003.

Szczurek J. D., Jurydyczny wymiar dogmatu, w: P. Majer, A. Wójcik (red.), Lex Tua veritas. Ksiega pamiatkowa dedykowana Jego Magnificencji Księdzu Profesorowi Janowi Maciejowi Dyduchowi z okazji 70. rocznicy urodzin, Kraków 2010, s. 307-314.

Szczurek J. D., Sakrament święceń, w: K. Porosło, R. J. Woźniak (red.), Znaki Tajemnicy. Sakramenty w teorii i praktyce Kościoła, Kraków 2018, s. 457-500.

Szczurek J. D., Trójjedyny. Traktat o Bogu w Trójcy Świętej jedynym, Kraków 2003. Thoma de Aquino, Summa theologiae, Roma 1962.

Wallner K. J., Gott als Eschaton. Trinitarische Dramatik als Voraussetzung göttlicher Universalität bei Hans Urs von Balthasar, Wien 1992.

Ks. prof. dr hab. Jan Daniel Szczurek - kapłan archidiecezji krakowskiej, pracownik naukowy Uniwersytetu Papieskiego Jana Pawła II w Krakowie, dyrektor Instytutu Teologii Dogmatycznej na Wydziale Teologicznym, sekretarz redakcji „Analecta Cracoviensia”. 